Bioscientia Medicina: Journal of Biomedicine \& Translational Research

Journal Homepage: www.bioscmed.com

\title{
Potential of Sriwijaya Thermal Cycler Smart Controlling-Based as a Tool for DNA Sequence Polymerase Chain Reaction
}

\author{
Msy Rulan Adnindya ${ }^{1^{*}}$, Indri Seta Septadina ${ }^{1}$, Muhammad Reagan² \\ ${ }^{1}$ Department of Anatomy, Faculty of Medicine, Universitas Sriwijaya, Palembang, Indonesia \\ ${ }^{2}$ Department of Internal Medicine, Faculty of Medicine, Universitas Sriwijaya, Palembang, Indonesia
}

\author{
A R T I C L E I N F O \\ Keywords: \\ COVID-19 \\ Control Groups \\ Severe Acute Respiratory Syndrome \\ Corona virus 2 \\ Polymerase Chain Reaction \\ DNA. \\ Corresponding author: \\ Msy Rulan Adnindya \\ E-mail address: \\ msy.rulan@gmail.com
}

All authors have reviewed and approved the final version of the manuscript.

\section{https://doi.org/10.32539/bsm.v5i4.208}

\begin{abstract}
A B S T R A C T
Background. Along with the COVID-19 pandemic, the need for a thermal cycler device for examining COVID-19 is getting bigger. Many laboratories have overused the use of thermal cyclers due to the limited availability of this tool. This study aims to test the effectiveness of the Sriwijaya thermal cycler based on a smart controller in conducting PCR DNA sequences. Methods. The research design was an experimental study with a posttest control group approach, in order to see an overview of the results of the polymerase chain reaction (PCR) in the form of intermediate DNA bands using Sriwijaya Thermal Cycler compared to groups using factory-made Thermal cyclers. Results. The PCR results showed precise results from the image and band separation, and there was a clear separation of the bands on the marker. The PCR results from the ACE I / D gene showed quite good and optimal results in the separation of the PCR results band. Conclusion. Sriwijaya thermal cycler is effective in DNA polymerase chain reaction (PCR) sequences comparable to that of the manufacturer's Thermal Cycler.
\end{abstract}

\section{Introduction}

Polymerase chain reaction (PCR) technique is a technology that is increasingly being used in various biomolecular and genetic examinations. ${ }^{1}$ PCR is a technique used to apply or multiply the DNA sequence so that the nitrogen base sequence in the DNA strand can be studied and assessed.2,3 Without carrying out the DNA sequence amplification process, it will not be easy to study the nitrogen base strands in DNA. The PCR technique, which was initially only performed for advanced research and not routine examinations, is now becoming recognized along with the use of this technique for the gold-standard examination for the diagnosis of COVID-19. Along with the COVID-19 pandemic, the need for a thermal cycler device for examining COVID-19 is getting bigger. Many laboratories have overused the use of thermal cyclers due to the limited availability of this tool. The need for a thermal cycler is increasing while the price of this tool in the market is relatively high. This encourages ideas and creativity to develop a thermal cycler device called the Sriwijaya thermal cycler based on a smart controller. This domestically produced thermal cycler device is much more economical and easy to use, so it is hoped that it can answer the need for domestic thermal cycler equipment.

Thermal cycler has a working principle of regulating the temperature regulation of annealing, denaturation and elongation. The ability of this tool to regulate 
temperature regulation and the length of exposure to temperature are essential points in the development of a smart controlling-based thermal cycler device. Arduino is used as a microcontroller that regulates the length of temperature exposure to the DNA sample. The use of the Arduino microcontroller is a critical point and the novelty of the thermal cycler technology being developed. This study aims to test the effectiveness of the Sriwijaya Thermal Cycler based on a smart controller in conducting PCR DNA sequences.

\section{Research Methods}

\section{Study design}

The research design was an experimental study with a posttest control group approach, in order to see an overview of the results of the polymerase chain reaction (PCR) in the form of intermediate DNA bands using Sriwijaya Thermal Cycler compared to groups using factory-made Thermal cyclers. The sample tested in this study was the DNA of healthy respondents, where this study has received approval from the Ethics Committee for Medical and Health Research, Faculty of Medicine, Universitas Sriwijaya (No.154 / KEPKKFKUNSRI / X / 2020).

\section{Preparation of DNA sequences for PCR}

A sample of $3 \mathrm{~mL}$ of blood was taken from a healthy individual and then inserted into an EDTA tube, then the blood sample was centrifuged at a speed of 5000 rpm, for 10 minutes, 25oC. The centrifuged supernatant was separated from the blood portion of the sample. The part that contains blood cells is used for the isolation of DNA from white blood cells. The next stage, the blood sample was isolated by DNA, starting with the sample mixed with $0.5 \%$ saponins in PBS $1 x$, then incubated for 4 hours and centrifuged at a speed of $12,000 \mathrm{rpm}$ for 10 minutes, resulting in precipitates. The precipitate was separated and added back with ddH2O, then again centrifuged. The precipitate was then added with 100ul ddH2O and 50 ul Chelex-100 $20 \%$, then boiled for 10 minutes, then returned to centrifuge at $12,000 \mathrm{rpm}$ for 10 minutes. The supernatant was collected and stored at $-20 \mathrm{oC}$ for PCR.
ACE I / D polymorphisms were examined using the polymerase chain reaction (PCR) method. In brief, $\mathrm{ACE}$ is obtained by a separate reaction, using an oligonucleotide. PCR primers were 5'GCCCTGCAGGTGTCTGCAGCATGT3' (forward primary) and 5'GGATGGCTCCCCGCCTTGTCTC3' (reverse primary). The final volume of the PCR reaction mixture was $20 \mu \mathrm{L}$ containing one $\mathrm{mM}$ of each primer (Invitrogen ${ }^{\circledR}$ ), $\quad 1.5 \mathrm{mM} \quad \mathrm{MgCl} 2, \quad 0.2 \mathrm{mM}$ of each deoxynucleoside triphosphate - dNTp, $2.5 \mu \mathrm{L}$ of $10 \mathrm{X}$ PCR Buffer and 0.5 U of Taq polymerase (Invitrogen ${ }^{\circledR}$ ). Amplification was performed in a thermocycler (Biorad $\left.{ }^{\circledR}\right)$ with an initial denaturation step at $94^{\circ} \mathrm{C}$ for 2 minutes followed by 40 cycles consisting of denaturation at $94^{\circ} \mathrm{C}$ for 10 seconds, annealing at 60 - $\mathrm{C}$ for 30 seconds and extension at $72^{\circ} \mathrm{C}$ for 30 seconds. PCR products were separated on $8 \%$ polyacrylamide gel and DNA visualized with silver nitrate. This gel is prepared with $15 \mathrm{~mL}$ of polyacrylamide solution, $129 \mu \mathrm{L}$ ammonium persulfate and $15 \mu \mathrm{L}$ TEMED $\left(\mathrm{N}, \quad \mathrm{N}, \quad \mathrm{N}, \quad \mathrm{N}^{\prime}-\right.$ Tetramethylethylenediamine). The DNA fragment measures $190 \mathrm{bp}$ for the D allele and $490 \mathrm{bp}$ for the I allele.

\section{Sriwijaya thermal cycler developing}

The manufacture of the thermal cycler device is carried out with a rectangular aluminium container. Furthermore, the construction of a thermal regulator with Wiremound resistors, 150 ohms / 50 Watts, Arctic Silver Thermal Epoxy, Solid-state relay 25A AC / DC SSR, MAX31855 breakout Thermocouple wire $60 \mathrm{~mm}$ fan 12 V 12 DC transistor, 0.5A power supply, Regular power cable was carried out. Furthermore, developing the Arduino microcontroller regulator coding and the final stage of construction will be carried out.

\section{Data analysis}

The data analysis in this study was carried out qualitatively by visualizing the comparison between the PCR results using a manufacturer's thermal cycler and the Sriwijaya thermal cycler. Comparison of the bands formed and the clarity of the band image are essential 
points in the PCR result comparison process.

\section{Results}

Figure 1 shows the results of the polymerase chain reaction (PCR) of the $\mathrm{ACE} \mathrm{I} / \mathrm{D}$ gene with these primers and reverses in the method. The PCR results showed precise results from the image and band separation, and there was a clear separation of the bands on the marker. The PCR results from the ACE I / D gene showed quite good and optimal results in the separation of the PCR results band.

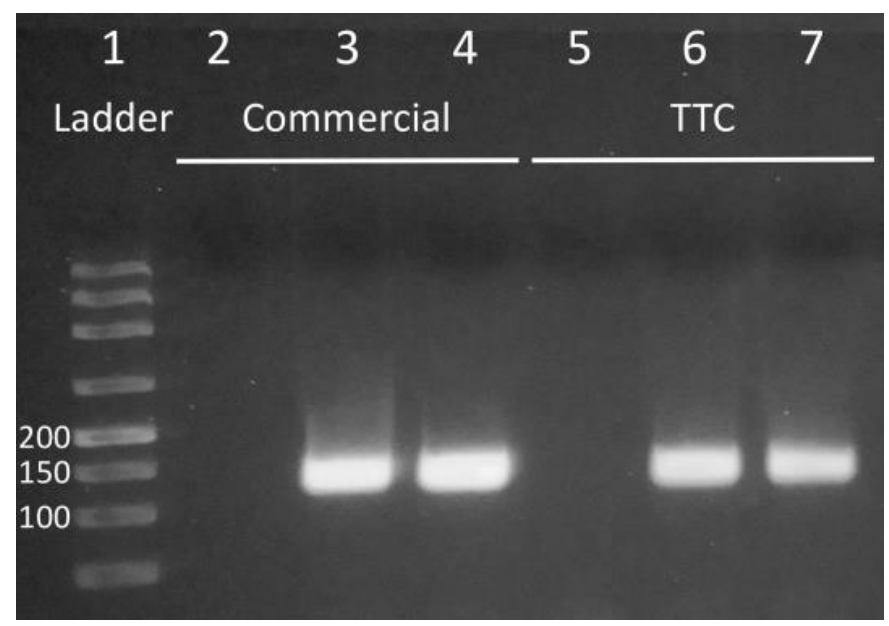

Figure 1. Comparison of PCR Results with Thermal Cycler Commercial and Thermal Cycler Creation (TTC)

\section{Discussion}

Sometimes called "molecular photocopying," the polymerase chain reaction $(\mathrm{PCR})$ is a fast and inexpensive technique used to "amplify" - copy - small segments of DNA.4-6 Because significant amounts of a sample of DNA are necessary for molecular and genetic analyzes, studies of isolated pieces of DNA are nearly impossible without PCR amplification. For amplifying a segment of DNA using PCR, the sample is first heated, so the DNA denatures or separates into two pieces of single-stranded DNA.7,8 Next, an enzyme called "Taq polymerase" synthesizes - builds - two new strands of DNA, using the original strands as templates. This process results in the duplication of the original DNA, with each of the new molecules containing one old and one new strand of DNA. Then each of these strands can be used to create two new copies, and so on, and so on. The cycle of denaturing and synthesizing new DNA is repeated as many as 30 or 40 times, leading to more than one billion exact copies of the original DNA segment. ${ }^{9-11}$

The entire cycling process of PCR is automated and can be completed in just a few hours. It is directed by a machine called a thermocycler, which is programmed to alter the temperature of the reaction every few minutes to allow DNA denaturing and synthesis. ${ }^{12-15}$ Sriwijaya Thermal Cycler with temperature control using a sufficient microcontroller as a thermal cycler. This study shows that the use of a microcontroller is beneficial and efficient to maintain the temperature regulator and heating time of the thermal cycler. The identical results between the thermal cycler manufacturer and the Sriwijaya thermal cycler show the potential and success of Arduino as a master temperature and heating time regulator of the thermal cycler.

\section{Conclusion}

Sriwijaya thermal cycler is effective in DNA polymerase chain reaction (PCR) sequences comparable to that of the manufacturer's Thermal Cycler. 


\section{References}

1. Butler D. Disease surveillance needs a revolution. Nature. 2006; 440(7080):6-7. PMID: 16511453

2. King DA, Peckham C, Waage JK, Brownlie J, Woolhouse MEJ. EPIDEMIOLOGY: Infectious Diseases: Preparing for the Future. Science. 2006; 313(5792):1392-3. doi: 10.1126/science.1129134 PMID: 16959992

3. Yager P, Edwards T, Fu E, Helton K, Nelson K, Tam MR, et al. Microfluidic diagnostic technologies for global public health. Nature. 2006; 442(7101):412-8. PMID: 16871209

4. Chin CD, Linder V, Sia SK. Lab-on-a-chip devices for global health: Past studies and future opportunities. Lab Chip. 2007; 7:41-57. PMID: 17180204

5. Thomas Weissensteiner T, Griffin HG, Griffin AM. PCR technology: current innovations. Boca Raton, FL: CRC Press LLC; 2004. 392 p.

6. Logan JMJ, Edwards KJ. An Overview of PCR Platforms. In: Logan J, Edwards K, Saunders N, editors. Real-Time PCR: Current Technology and Applications London: Caister Academic Press; 2009.

7. Viedma DGd. Rapid detection of resistance in Mycobacterium tuberculosis: a review discussing molecular approaches. Clinical Microbiology \& Infection. 2003; 9(5):349-59.

8. Nachamkin I, Kang C, Weinstein P. Detection of resistance to isoniazid, rifampin and streptomycin in clinical isolates of Mycobacterium tuberculosis by molecular methods. Clin Infect Dis. 1997; 24:894- 900. PMID: 9142789

9. Yang S, Rothman RE. PCR-based diagnostics for infectious diseases: uses, limitations, and future applications in acute-care settings. Lancet Infect Dis. 2004; 4:337. PMID: 15172342

10. Oh M-H, Paek S-H, Shin GW, Kim H-Y, Jung GY, Oh S. Simultaneous Identification of Seven
Foodborne Pathogens and Escherichia coli (Pathogenic and Nonpathogenic) Using Capillary ElectrophoresisBased Single-Strand Conformation Polymorphism Coupled with Multiplex PCR. Journal of Food Protection. 2009; 72(6):1262-6. PMID: 19610337

11. Brooks HA, Gersberg RM, Dhar AK. Detection and quantification of hepatitis $A$ virus in seawater via real-time RT-PCR. Journal of Virological Methods. 2005; 127(2):109-18. PMID: 15896854

12. Noble RT, Blackwood AD, Griffith JF, McGee CD, Weisberg SB. Comparison of Rapid Quantitative PCR-Based and Conventional Culture-Based Methods for Enumeration of Enterococcus spp. and Escherichia coli in Recreational Waters. Appl Environ Microbiol. 2010; 76(22):7437-43. doi: 10.1128/ aem.00651-10 PMID: 20870786

13. Liu P, Seo TS, Beyor N, Shin K-J, Scherer JR, Mathies RA. Integrated Portable Polymerase Chain Reaction-Capillary Electrophoresis Microsystem for Rapid Forensic Short Tandem Repeat Typing. Analytical Chemistry. 2007; 79(5):1881-9. PMID: 17269794

14. Mannucci A, Sullivan KM, Ivanov PL, Gill P. Forensic application of a rapid and quantitative DNA sex test by amplification of the X-Y homologous gene amelogenin. International Journal of Legal Medicine. 1994; 106(4):190-3. PMID: 8038111

15. Lin $\mathrm{M}-\mathrm{H}$, Tseng C-H, Tseng C-C, Huang C-H, Chong C-K, Tseng C-P. Real-time PCR for rapid genotyping of angiotensin-converting enzyme insertion/deletion polymorphism. Clinical Biochemistry. 2001; 34(8):661-6. PMID: 11849627 